\title{
Innate and adaptive immune interactions at the fetal-maternal interface in healthy human pregnancy and pre-eclampsia
}

\author{
Peter Hsu ${ }^{1,2,3}$ and Ralph Kay Heinrich Nanan ${ }^{1,3}$ * \\ Charles Perkins Centre Nepean, Penrith, NSW, Australia \\ 2 Department of Allergy and Immunology, The Children's Hospital at Westmead, Sydney, NSW, Australia \\ ${ }^{3}$ Sydney Medical School, The University of Sydney, Sydney, NSW, Australia
}

\section{Edited by:}

Sinuhe Hahn, University Hospital Basel, Switzerland

Reviewed by:

Fulvio D'Acquisto, Queen Mary University of London, UK

Cecilia Garlanda, Istituto Clinico

Humanitas, Italy

*Correspondence:

Ralph Kay Heinrich Nanan, Sydney

Medical School Nepean, The

University of Sydney, Level 5, The

Spurrett Building, Nepean Hospital,

P.O. Box 63, Penrith NSW 2751 ,

Australia

e-mail:ralph.nanan@sydney.edu.au

\begin{abstract}
Maternal immune tolerance of the fetus is indispensable for a healthy pregnancy outcome. Nowhere is this immune tolerance more important than at the fetal-maternal interface - the decidua, the site of implantation, and placentation. Indeed, many lines of evidence suggest an immunological origin to the common pregnancy-related disorder, pre-eclampsia. Within the innate immune system, decidual NK cells and antigen presenting cells (including dendritic cells and macrophages) make up a large proportion of the decidual leukocyte population, and are thought to modulate vascular remodeling and trophoblast invasion. On the other hand, within the adaptive immune system, Foxp3 $^{+}$regulatory $T$ cells are crucial for ensuring immune tolerance toward the semi-allogeneic fetus. Additionally, another population of $\mathrm{CD} 4^{+} \mathrm{HLA}_{-} \mathrm{G}^{+}$suppressor $\mathrm{T}$ cells has also been identified as a potential player in the maintenance of immune tolerance. More recently, studies are beginning to unravel the potential interactions between the innate and the adaptive immune system within the decidua, that are required to maintain a healthy pregnancy. In this review, we discuss the recent advances exploring the complex crosstalk between the innate and the adaptive immune system during human pregnancy.
\end{abstract}

Keywords: pregnancy, pre-eclampsia, $\mathrm{T}$ regulatory cells, decidual, $\mathrm{NK}$ cells, $\mathrm{CD}^{+} \mathrm{HLA}^{-\mathrm{G}^{+}}$, dendritic cells

\section{INTRODUCTION}

Pregnancy presents a significant challenge to the maternal immune system. In humans, the maternal immune system must tolerate the semi-allogeneic fetus throughout the 9 months of pregnancy. The remarkable nature of this phenomenon was recognized by Peter Medawar in the 1950s (1), whose work on skin graft rejection in genetically different individuals, led him to perceive this apparent immunological paradox. At the time, he proposed that three factors contribute to this phenomenon: (1) the anatomical separation between the mother and the fetus, (2) the reduced antigenic property of the fetus, and (3) the immunological inertness of the maternal immune system.

These proposals have significantly influenced subsequent research in the field. Indeed, it is now well-known that fetal cells are largely separated from the maternal immune system, with the point of contact being fetal extravillous trophoblast (EVT) cells, which have poor antigenic properties owing to the lack of expression of classical MHC class I (except HLA-C) and MHC class II molecules (2). However, as fetal-maternal microchimerism is a well-recognized occurrence during human pregnancy, fetal cells frequently induce maternal immune activation $(3,4)$ as evidenced by the detection of anti-fetal HLA antibodies in maternal serum during pregnancy $(5,6)$. Additionally, although direct MHC presentation of fetal antigens by fetal cells generally does not occur, fetal antigens can be processed and presented by maternal antigen presenting cells (APCs) at the fetal-maternal interface (7).
Indeed, various different subsets of maternal immune cells are present at the fetal-maternal interface, which is the decidua, the mucous membrane (endometrium) of the pregnant uterus. In fact, up to $50 \%$ of the cells in the decidua are maternal immune cells (8). The decidua is therefore, an important site where the maternal immune system encounters fetal antigens and must develop tolerance mechanisms.

Not surprisingly, many of the pregnancy-related disorders such as recurrent miscarriages and pre-eclampsia are thought to be due to the breakdown of this immune tolerance $(6,9,10)$. In pre-eclampsia, whilst the clinical manifestations such as hypertension and proteinuria are thought to be due to endotheliopathy secondary to insufficient placentation $(11,12)$, the shallow fetal trophoblast invasion is likely related to partial breakdown of maternal-fetal immune tolerance (9).

In this review, we will explore the role of decidual innate and the adaptive immune cells in facilitating tolerance to the fetus. In particular, we will highlight some of the recent advances documenting the interaction between these cells, drawing comparisons between healthy human pregnancy and pre-eclampsia.

\section{INNATE IMMUNE CELLS AT THE FETAL-MATERNAL INTERFACE}

DECIDUAL ANTIGEN PRESENTING CELLS DURING PREGNANCY

Antigen presenting cells are likely to be important players in the mediation of immune tolerance in the decidua. In mice, a previous 
study has shown that maternal APCs take up apoptotic debris from the fetal/placental cells and present fetal antigens to maternal $\mathrm{T}$ cells. As the major histocompatibility antigens (classical MHC I and II antigens) are suppressed on fetal trophoblast cells to evade maternal immune recognition, antigen presentation of fetal minor histocompatibility antigens by maternal APCs is an important route for immune recognition (7). Therefore, exploring the characteristics of the decidual APCs and their interaction with decidual $\mathrm{T}$ cells is of great importance in the understanding of fetal-maternal immune tolerance.

\section{DECIDUAL DENDRITIC CELLS IN HEALTHY PREGNANCY AND PRE-ECLAMPSIA}

Study of decidual dendritic cells (dDCs) has been difficult, not only because isolation of decidual cells including dDCs can be technically demanding, but also because phenotypic definition of DCs is controversial as there is no single specific marker for DCs. In this particular section, we refer primarily to the lineage negative HLA-DR ${ }^{+}$classical DCs. Using lineage negative and HLA-DR ${ }^{+}$as combination marker for dendritic cell (DC), Gardener et al. found that dDC comprises $\sim 1 \%$ of the total decidual cell isolates in first trimester decidua (13). These DCs were CD11c ${ }^{+}, \mathrm{CD}^{-} \mathrm{a}^{-}$, and $\mathrm{CD}_{12}{ }^{-}$, indicating a myeloid rather than plasmacytoid origin. Interestingly, they showed that these DCs were DC-SIGN ${ }^{-}$, compared to CD14 " "macrophages," which were DC-SIGN ${ }^{+}$. These results were further explored in a later study by Ban et al., who showed that first trimester lineage negative and HLA-DR ${ }^{+} \mathrm{dDCs}$ predominantly expressed BDCA1 and BDCA3 surface antigens, corresponding with different subsets of myeloid DCs (14).

Overall, due to the difficulty in decidual mononuclear cell isolation and the rarity of dDCs, functional studies on these DCs are scarce. In a study by Kammerer et al., the authors demonstrated a small population of mature $\mathrm{CD}^{+} 3^{+} \mathrm{DCs}$ as well as CD1a ${ }^{+} \mathrm{DCs}$ in human first trimester decidua, by both immunohistochemistry and flow cytometry (15). They went on to show that the CD83 ${ }^{+}$ cells are potent stimulators in mixed lymphocyte reactions comparable to mature peripheral blood monocyte-derived DCs. Another study by Laskarin et al. showed that CD1a ${ }^{+}$DC isolated from decidua stimulated NK cell activity and proliferation better than decidual CD83 ${ }^{+}$DCs (16). Their experiments were done in vitro, however, and there was no demonstration of $\mathrm{CD} \mathrm{a}^{+}$or $\mathrm{CD} 83^{+} \mathrm{DC}$ interaction with decidual NK cells in situ. An earlier study demonstrated that lineage - and HLA-DR ${ }^{+}$DCs in first trimester human decidua were mostly of myeloid origin, but produced less IL-12 compared to their peripheral counterparts. They also showed that dDCs were more likely to prime CD4 cells into a Th2 phenotype compared to their peripheral counterparts (17). The authors concluded that such polarization of the immune response toward Th2 has potential roles in averting Th1-mediated rejection of the fetus.

Studies of decidual DC functions in mice are more definitive. Selective ablation of $\mathrm{CD} 11 \mathrm{c}^{+}$decidual DCs leads to failure of decidualization and embryo implantation (18), highlighting the potential role of $\mathrm{dDCs}$ in the initiation of successful pregnancy. Another study demonstrated that during murine pregnancy, decidual $\mathrm{CD}_{11 \mathrm{c}^{+}}$DCs fail to migrate to draining lymph nodes due to absent lymphatic vessels and CCL21 (ligand for lymphoid homing CCR7) expression in the murine decidua and therefore do not significantly contribute to anti-fetal $\mathrm{T}$ cell responses (19). However, it is important to note that in contrast to mice, lymphatic vessels are abundant and CCL21 is expressed within the human decidua $(20,21)$, which therefore might facilitate decidual DC migration in humans. Furthermore, whilst these studies shed light on the function of CD11 $\mathrm{c}^{+}$DCs in mice, it is difficult to know whether these $\mathrm{CD} 11 \mathrm{c}^{+}$cells are comparable to the lineage negative, HLA-DR ${ }^{+} \mathrm{CD} 11 \mathrm{c}^{+}$DCs in human decidua. Nevertheless, at least in mice, decidual CD11c ${ }^{+}$DCs appear to be important for the initiation of pregnancy and maintenance of immune tolerance.

So far, few studies have examined the role of decidual DCs in pre-eclampsia. Huang et al. found that there were increased numbers of $\mathrm{CD}^{2} 3^{+}$and DC-SIGN ${ }^{+}$APCs in the pre-eclamptic decidua (22). Scholz et al. partially confirmed this finding showing increased numbers of DC-SIGN ${ }^{+}$cells in the decidua of patients affected by HELLP syndrome, a severe form of pre-eclampsia (23). However, it is important to note that $\mathrm{DC}^{-\mathrm{SIGN}^{+}}$APCs in particular, are likely a different group of cells distinct from lineage negative

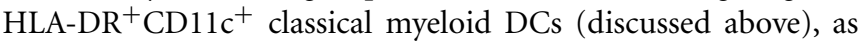
highlighted in subsequent sections.

\section{DECIDUAL MACROPHAGES IN HEALTHY PREGNANCY AND PRE-ECLAMPSIA}

Macrophages are specialized phagocytic cells of the innate immune system and they are present in every organ of the body in one form or another. Macrophages, like DCs, are part of the mononuclear phagocyte system consisting of committed bone marrow precursors, peripheral blood monocytes and DCs, as well as tissue macrophages and DCs (24). Whilst many have attempted to separate macrophages from DCs based on phenotype and function, significant controversy exists as to whether these cells are indeed distinct from one another (25).

$\mathrm{CD}_{14}{ }^{+}$decidual macrophages (dMacs) comprise about 10 $20 \%$ of decidual CD $45^{+}$leukocyte population (26). Their phenotype has been characterized in several studies. In a study of human $\mathrm{CD}_{14}{ }^{+}$dMacs, Heikinnen et al. (27) observed that compared to the peripheral blood monocytes, dMacs expressed lower level of co-stimulatory molecule CD86. This coupled with the expression of indoleamine 2,3-dioxygenase (IDO), known to have an immunosuppressive effect on $\mathrm{T}$ cells, led them to conclude that dMacs have an "immunosuppressive" phenotype. Notably however, their data showed that dMacs expressed higher level of HLA-DR, as well as the co-stimulatory molecule CD80, compared to peripheral blood monocytes. Another study by Repnik et al. (28) confirmed the expression of HLA-DR, CD80, and CD86 on dMacs. They further showed that expression of these markers were higher earlier in the gestation, implying greater dMac activation at the time of implantation. A more recent study examined $\mathrm{dMac}$ in the first trimester using gene micro-array analysis. The authors found that compared to peripheral blood macrophages, dMacs have a gene expression profile, which biases toward alternatively activated macrophages or M2 phenotype, which suggests that dMacs are likely immunosuppressive (29).

In a study of dMac function, Mizuno et al. (30) showed that dMacs have antigen presentation capacity, but are less stimulatory and produce less IL-1 than peripheral blood monocytes in 
mixed lymphocyte reactions. The suppressive activity of dMac has also been supported by other studies (31). The cytokine profile of dMac was also examined by Heikkinen et al., showing that term decidual $\mathrm{CD} 14^{+} \mathrm{dMac}$ spontaneously produced significantly more IL-10 than peripheral blood monocytes ex vivo. In addition, these macrophages were less able to differentiate into mature DCs in vitro under polarizing conditions, possibly owing to their production of IL-10 (27). Thus, it is likely that dMacs are a special subset of APCs specialized in tolerance induction. In addition, there is evidence that dMacs are also involved in vascular remodeling $(5,32)$ and parturition in the peripartum period $(33,34)$.

In a large study with 33 pre-eclamptic patients and 66 controls, Rieger et al. examined decidual leukocyte populations using flow cytometry (35). They did not find any difference in HLA-DR, dendritic cell specific intercellular adhesion molecule 3 (ICAM3) grabbing non-integrin (DC-SIGN), or CD14 expression within $\mathrm{CD}_{4}{ }^{+}$cells between healthy pregnancy and pre-eclampsia. In a smaller study, Schonkeren et al. compared the distribution and phenotype of $\mathrm{CD} 14^{+} \mathrm{dMacs}$ between preterm control pregnancies and preterm pre-eclampsia (36). Using sequential or two-color immunohistochemistry, they found reduced CD163/CD14 ratio [CD163 being a marker of alternatively activated macrophage or M2 (37)], increased DC-SIGN/CD14 ratio, and reduced IL10 expression in preterm pre-eclamptic pregnancies, which may suggest a more pro-inflammatory phenotype of dMacs in preeclampsia. More recently, we examined decidual CD14 ${ }^{+}$APCs in more detail during healthy pregnancy and pre-eclampsia using multi-color flow cytometry (38). However, in this study, we focused on the distinct subset of $\mathrm{CD} 14^{+} \mathrm{DC}-\mathrm{SIGN}^{+}$APCs, which is discussed below.

\section{DECIDUAL CD14+ ${ }^{+}$C-SIGN ${ }^{+}$APCs IN HEALTHY PREGNANCY AND PRE-ECLAMPSIA}

Dendritic cell specific ICAM3 grabbing non-integrin is an ICAM3 receptor, where ICAM3 is an adhesion molecule. DC-SIGN, also known as CD209, is important for the initiation of DC and T cell interaction (39). Despite its name, DC-SIGN may be expressed by a variety of APCs other than classical lineage negative HLA$\mathrm{DR}^{+}$DCs, including CD14 ${ }^{+}$macrophages (40). Nevertheless, in monocyte-derived DCs, DC-SIGN is one of the markers upregulated in maturing DCs in mice (33) and humans (39). Therefore, whilst the expression of DC-SIGN is not DC specific, it probably marks myeloid cells, which are on the DC differentiation pathway (i.e., immature DCs).

In the human decidua, Kammerer et al. found that a significant percentage of $\mathrm{CD}_{14}{ }^{+} \mathrm{HLA}-\mathrm{DR}^{+}$APCs expressed DC-SIGN in the first trimester decidua (41). These $\mathrm{CD} 4^{+}{ }^{+} \mathrm{DC}-\mathrm{SIGN}^{+}$cells did not express CD83, but expressed CD4. Interestingly, the authors found these cells to be unique to the decidua in pregnancy and not in normal non-pregnant endometrium. In addition, these cells show a high proliferative rate and good antigen uptake, but poor stimulatory activity in MLR. Importantly, these cells have a veiled appearance typical of immature DCs on immunohistochemistry and can be matured in vitro with a cocktail of inflammatory cytokines into $\mathrm{CD}^{+} 3^{+}$mature DCs, with decreased CD14 and DC-SIGN expression, as well as potent stimulatory activity in MLR. The authors concluded that these CD14 ${ }^{+} \mathrm{DC}$ $\mathrm{SIGN}^{+}$cells are likely to be precursors of DCs and may play an important role in mediating fetal-maternal immune tolerance. Repnik et al. also confirmed DC-SIGN expression in decidual CD14 ${ }^{+}$APCs and showed that DC-SIGN expression peaked in the second trimester (28). Obviously, decidual CD $14^{+}{ }^{D C}-S_{G N}{ }^{+}$ APCs would be included in studies examining dMacs in view of their CD14 expression. Such studies include recent work by Svensson et al., who showed that $\mathrm{CD} 14^{+}$dMacs can be divided into two distinct groups based on ICAM3 expression, with the ICAM3 $^{-}$group expressing DC-SIGN and markers of alternative (M2) macrophage activation (CD163, CD206, neuropilin) (42). They further showed that the phenotype of these DC-SIGN ${ }^{+}$ dMacs may be replicated in vitro (with similar gene expression profile) in the presence of M-CSF (and/or GM-CSF) plus IL-10. Another study divided first trimester CD14 ${ }^{+}$dMacs into CD $11 c^{\text {hi }}$ and CD $11 \mathrm{c}^{\text {lo }}$ cells corresponding to DC-SIGN ${ }^{-}$and DC-SIGN ${ }^{+}$ cells, respectively (43). Using gene expression profiles, the authors here showed that neither of the CD1 $1 c^{\text {hi }}$ or CD $11 c^{\text {lo }}$ macrophages corresponds to in vitro differentiated M1 or M2 macrophages exactly, though CD11 $c^{\text {hi }}$ macrophages were skewed toward maternal peripheral blood monocytes and shared common genes with synovial macrophages from rheumatoid arthritis patients. In the same study, the authors showed that CD11 $\mathrm{c}^{\text {hi }} \mathrm{dMac}$ produced significantly more TNF $\alpha$, IL-6, and paradoxically IL-10 compared to CD11 $c^{\text {lo }}$ macrophages. On the other hand, there was a slight trend toward increased TGF $\beta$ secretion by CD11 $c^{\text {lo }}$ cells.

Collectively, these studies confirm that the human decidua harbors two distinct populations of $\mathrm{CD} 14^{+} \mathrm{APCs}$, one which is $\mathrm{CD}_{11 \mathrm{c}^{\mathrm{lo}} \mathrm{DC}-\mathrm{SIGN}}{ }^{+} \mathrm{CD} 206^{+} \mathrm{CD} 163^{+}$neuropilin ${ }^{+} \mathrm{ICAM}^{-}$and is likely immunoregulatory and important for tolerance induction, the other which is $\mathrm{CD} 11 \mathrm{c}^{\text {hi DC-SIGN }}{ }^{-} \mathrm{CD} 206^{-} \mathrm{CD} 163^{-}$ neuropilin ${ }^{-}$ICAM3 $^{+}$and probably pro-inflammatory and important for tissue remodeling. In our recent study, we examined term decidual $\mathrm{CD} 14^{+} \mathrm{DC}^{\mathrm{DSIGN}}{ }^{+} \mathrm{APCs}$ in detail using multi-color flow cytometry. We show that decidual CD $14^{+} \mathrm{DC}^{-S I G N}{ }^{+}$APCs expressed significantly higher amount of tolerogenic molecules (HLA-G and ILT4), lymphoid homing molecule (CCR7), as well as antigen presentation apparatus (HLA-DR, CD80, CD86), but less CD14 than $\mathrm{CD}_{14}{ }^{+} \mathrm{DC}^{\mathrm{SIGN}}{ }^{-}$cells (38). This suggests that decidual CD $14^{+}$DC-SIGN $^{+}$APCs may be further along the differentiation pathway than their DC-SIGN ${ }^{-}$counterparts and that these cells possess enhanced tolerogenic properties. Both of these observations are consistent with the previously described studies (42, 43). The tolerogenic properties are likely induced by IL-10, which is known to upregulate HLA-G and ILT4 $(44,45)$. Interestingly in vitro, we were able to differentiate peripheral blood monocytes into $\mathrm{CD}_{14}{ }^{+} \mathrm{DC}^{\mathrm{DIGN}}{ }^{+} \mathrm{HLA}_{-G^{+}} \mathrm{ILT}^{+}{ }^{+}$APCs by adding IL-10 to the DC polarizing protocol (with GM-CSF and IL-4) (46). In the context of the blurred border between macrophages and DCs, and given that the phenotype of decidual DC-SIGN ${ }^{+}$APCs may be replicated in vitro with both $\mathrm{DC}$ or macrophage polarizing protocols, we suggest that decidual $\mathrm{CD} 14^{+} \mathrm{DC}-\mathrm{SIGN}^{+}$APCs are likely an intermediate cell type on the continuum of macrophage/DC differentiation under the influence of IL-10. Whether decidual $\mathrm{CD}_{14}^{+}{ }^{+} \mathrm{DC}-\mathrm{SIGN}^{-}$APCs are completely distinct from, or on the same developmental continuum as, $\mathrm{CD} 14^{+} \mathrm{DC}-\mathrm{SIGN}^{+} \mathrm{APCs}$ is 
Table 1 | Differences between decidual DC-SIGN ${ }^{+}$and DC-SIGN ${ }^{-}$APCs.

\begin{tabular}{|c|c|c|}
\hline & DC-SIGN ${ }^{+}$ & DC-SIGN ${ }^{-}$ \\
\hline \multicolumn{3}{|l|}{ LINEAGE MARKER } \\
\hline CD14 (38) & Intermediate & High \\
\hline CD4 (41) & Intermediate & Low \\
\hline \multicolumn{3}{|c|}{ ANTIGEN PRESENTATION APPARATUS (38) } \\
\hline HLA-DR & High & Intermediate \\
\hline CD80 & High & Low \\
\hline CD86 & High & Intermediate \\
\hline \multicolumn{3}{|c|}{ ADHESION MOLECULES } \\
\hline CD11c (43) & Low & High \\
\hline ICAM3 (42) & Low & High \\
\hline CCR7 (38) & High & Low \\
\hline \multicolumn{3}{|l|}{ M2 MARKERS (42) } \\
\hline CD163 & High & Low \\
\hline Neuropilin & High & Low \\
\hline \multicolumn{3}{|c|}{ TOLEROGENIC MOLECULES (38) } \\
\hline HLA-G & High & Low \\
\hline ILT4 & High & Intermediate \\
\hline \multicolumn{3}{|c|}{ CYTOKINE PRODUCTION (43) } \\
\hline TNF $\alpha$, IL-6 & Low & High \\
\hline IL-10 & Low & High \\
\hline TGF $\beta$ & High & Intermediate \\
\hline $\begin{array}{l}\% \text { CD14+ cells (first } \\
\text { trimester) (43) }\end{array}$ & $\sim 70 \%$ & $20-30 \%$ \\
\hline In vitro differentiation & $\begin{array}{l}\mathrm{M}-\mathrm{CSF} \pm \mathrm{GM}-\mathrm{CSF}+\mathrm{IL}-10(42) \\
\mathrm{GM}-\mathrm{CSF}+\mathrm{IL}=4+\mathrm{IL}-10\end{array}$ & Unknown \\
\hline $\begin{array}{l}\text { In vitro differentiation } \\
\text { to } D C(41)\end{array}$ & Yes & Probably \\
\hline Likely function & Immune regulation & $\begin{array}{l}\text { Tissue } \\
\text { remodeling }\end{array}$ \\
\hline
\end{tabular}

currently unknown. However, the later hypothesis is supported by the fact that $\mathrm{CD} 14^{+}$DC-SIGN ${ }^{-}$APCs are closer to peripheral blood monocytes (43) and possess less antigen presentation apparatus. The differences between decidual $\mathrm{CD} 14^{+} \mathrm{DC}-\mathrm{SIGN}^{+}$and $\mathrm{CD}_{14}^{+}{ }^{\mathrm{DC}}$-SIGN ${ }^{-}$APCs are summarized in Table 1.

Interestingly in pre-eclampsia, we found an increased percentage of $\mathrm{DC}-\mathrm{SIGN}{ }^{+} \mathrm{APC}$ within the $\mathrm{CD}_{14}{ }^{+}$population, however, pre-eclamptic decidual CD $14^{+}$DC-SIGN ${ }^{+}$APCs expressed significantly less HLA-G and ILT4 compared to the same cells in healthy pregnancy, suggestive of reduced tolerogenic capacity. We speculate that this phenotypic difference may be related to the reduced placental IL-10 levels in pre-eclamptic pregnancies (47).

In summary, there are several different types of APCs present in the decidua, including lineage negative $\mathrm{HLA}_{-} \mathrm{DR}^{+} \mathrm{CD} 11 \mathrm{c}^{+}$classical DCs, mature CD83 ${ }^{+}$DCs, CD1a ${ }^{+}$DCs, and CD $14^{+}$DC$\mathrm{SIGN}^{-} \mathrm{dMac}$, which may have developed from peripheral blood monocytes and are probably precursors to decidual CD $14^{+} \mathrm{DC}$ $\mathrm{SIGN}^{+}$APCs. Their potential relationships and differences in healthy pregnancy and pre-eclampsia are summarized in Figure 1.

\section{DECIDUAL NK CELLS IN HEALTHY PREGNANCY AND PRE-ECLAMPSIA}

Decidual NK cells (dNK) are the most abundant maternal leukocytes in the decidua, especially in the first trimester, making up $70 \%$ of the maternal CD $45^{+}$leukocyte population. (48) The dNK cells are distinct from majority of peripheral blood NK cells, in that they are large, granular, and are CD56 ${ }^{\mathrm{hi}}$ and $\mathrm{CD}^{-} 6^{-}$(8). The origin of these cells is unclear, although some have proposed possible recruitment of a subset of peripheral blood CD56 ${ }^{\text {hi }} \mathrm{NK}$ cells into the decidua (49). Interestingly, during early pregnancy, dNK accumulate as a dense infiltrate around the trophoblast cells, but they progressively decrease in number from mid-gestation onward (50). This timing seems to implicate that $\mathrm{dNK}$ cells may be involved in modulating trophoblast invasion and vascular remodeling. Indeed, $\mathrm{dNK}$ have been shown to produce vascular endothelial growth factor C (VEGFC), placental growth factor (PIGF), and angiopoietin 2 (ANG2).

Decidual NK cells may also be important in modulating the degree of trophoblast invasion, as they are seen in close proximity to the invading trophoblasts in the decidua. Certainly, dNK have been shown to express killer inhibitory receptor (KIR) (51), CD94/NKG2A (52), and ILT2 (53), which recognize HLA-C and HLA-G, respectively, expressed on trophoblast cells. The HLA-CKIR interaction is thought to be important in the pathogenesis of pre-eclampsia. As HLA-C is dimorphic and KIR polymorphic, it has been shown that certain combinations of maternal KIR and fetal HLA-C lead to an increased risk of pre-eclampsia, possibly through modulation of trophoblast migration, implying that HLA-C-KIR interaction is important in placentation (54, 55). However, NK cell KIR and HLA-C mismatch clearly does not explain all cases of pre-eclampsia, since only $30 \%$ of pre-eclamptic pregnancies have the at-risk maternal KIR phenotype (KIR AA) (54). HLA-G-ILT2 interaction on NK cells on the other hand, has been shown to increase $\mathrm{dNK}$ secretion of inflammatory and proangiogenic factors such as IL- $1 \beta$, IL-6, TNF, and IL-8 (56). NK cells themselves are also susceptible to modulation by the decidual cytokine milieu. Indeed, dNK cells are thought to be the mediator of fetal demise in IL-10-deficient mice treated with LPS, which conversely can be rescued by administration of IL-10 (57). This suggests that IL-10 may modulate dNK cell cytotoxicity.

Collectively, these data suggest that dNK cells are important for modulation of trophoblast invasion and decidual vascularization in pregnancy. However, the recognition and tolerance of paternal allo-antigens via APC presentation during pregnancy, clearly requires the participation of other limbs of the immune system, such as the adaptive immune cells.

\section{ADAPTIVE IMMUNE CELLS AT THE FETAL-MATERNAL INTERFACE}

The adaptive immune system distinguishes itself from the innate immune system by its antigen specificity and immunological memory. Therefore, the fact that pre-eclampsia is essentially a disease of primigravida and subsequent pregnancies with the same partner protect against pre-eclampsia $(58,59)$, supports the involvement of the adaptive immune system. Within the lymphocyte subsets, $\mathrm{CD} 4{ }^{+} \mathrm{Foxp}^{+}{ }^{+}$regulatory $\mathrm{T}$ (Treg) cells in particular have been the subject of many studies, with their pivotal role in pregnancy now firmly established. Th17 cells, the 

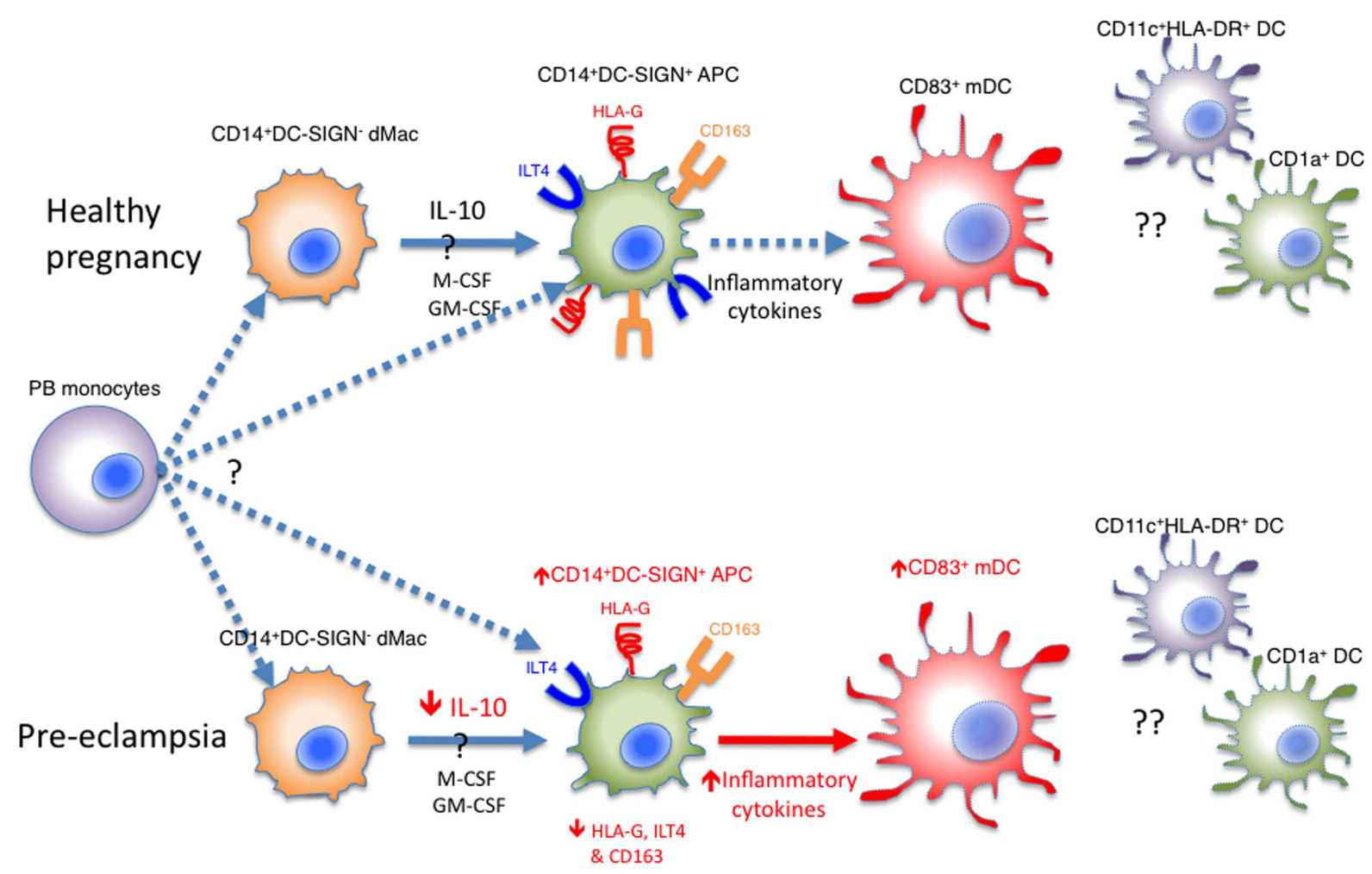

FIGURE 1 | Various APCs in the human decidua. Whether decidual CD14+DC-SIGN ${ }^{-}$dMacs and CD14+DC-SIGN ${ }^{+}$APCs are derived independently from peripheral blood (PB) monocytes is unknown. Alternatively, CD14+DC-SIGN- dMacs may be on a continuum of DC differentiation, where local IL-10, M-CSF, and GM-CSF drive their development into CD14+ DC-SIGN ${ }^{+}$APCs expressing HLA-G and ILT4. These APCs may be matured into $\mathrm{CD} 83^{+}$mature $\mathrm{DCs}$ (mDCs) under the influence of inflammatory cytokines, which in healthy pregnancy is minimal. In pre-eclampsia, both CD14+DC-SIGN ${ }^{+}$APCs and mDCs increase, probably driven by increased inflammatory cytokines in this disease. This is coupled with reduced HLA-G and ILT4 expression by CD14+DC-SIGN ${ }^{+}$APCs, likely due to reduced local IL-10 levels. Whilst $\mathrm{CD}_{11} \mathrm{c}^{+} \mathrm{HLA}-\mathrm{DR}^{+}$and $\mathrm{CD} 1 \mathrm{a}^{+} \mathrm{DC}$ s have been identified in human decidua, their roles and relationship with $\mathrm{CD} 3^{+} \mathrm{DC}$ are unclear. pro-inflammatory antagonist of Treg cells have also become a focus of studies in the last few years. More recently, $\mathrm{CD}^{+}{ }^{+} \mathrm{HLA}-\mathrm{G}^{+}$suppressor $\mathrm{T}$ cells have also been implicated for their potential role in healthy pregnancy and pre-eclampsia. Whilst other cells within the adaptive immune system such as Th1, Th2, gamma-delta $\mathrm{T}$ cells, and $\mathrm{CD}^{+} \mathrm{T}$ cells also play a role in fetal-maternal immune tolerance (60-63), our focus in this review will be on Treg, Th17, and $\mathrm{CD}^{+}{ }^{+} \mathrm{HLA}-\mathrm{G}^{+}$suppressor $\mathrm{T}$ cells.

\section{Treg CELLS IN HEALTHY PREGNANCY AND PRE-ECLAMPSIA}

Foxp $3^{+}$Treg cells are a unique subset of suppressive CD4 ${ }^{+} \mathrm{T}$ helper cells indispensable for immune tolerance to self- and foreign-antigens in humans and mice (64-67). Several authors have shown that in pregnancy, there is an expansion of peripheral blood Treg cell pool in both humans $(68,69)$ and mice $(70)$. The study by Somerset et al. showed that Treg cell population seems to peak in the second trimester and thereafter decreases to slightly above normal levels at delivery of the conceptus. Some have suggested that this expansion of Treg cell is not allo-antigen driven at least in the mice, as both syngeneically and allogeneically pregnant mice show expansion of the Treg cell population (70). However, the authors did not show a direct comparison of Treg cell percentage between syngeneic and allogeneic pregnancies. In contrast, Zhao et al. showed through direct comparison, that the percentage of peripheral blood Treg cells in allogeneic pregnancy is higher compared to syngeneic pregnancy, suggesting that the expansion of Treg cell is at least partially allo-antigen driven (71). Since then, other studies have demonstrated the fetal antigen-specific nature of maternal Treg cells during pregnancy $(72,73)$, further supporting the role of fetal allo-antigen in Treg cell expansion. Therefore, whilst other factors such as pregnancy-related hormones can also contribute to Treg cell expansion (74-76), it is likely that fetal allo-antigen stimulation is the primary driving force.

Given the decidua is the fetal-maternal interface and the likely place of fetal antigen encounter, it is not surprising that the proportion of Treg cells is even greater in the decidua during pregnancy compared to the peripheral blood $(77,78)$. The question is whether these Treg cells are recruited from the peripheral blood or induced locally. Currently in humans, despite some controversy, the only marker that differentiates thymus-derived natural Treg (nTreg) cells from peripherally induced Treg (iTreg) is Helios, where Helios ${ }^{+}$Treg cells are nTreg cells, which have acquired Treg cell phenotype in the thymus, whereas Helios ${ }^{-}$Treg cells have differentiated in the peripheral tissues/lymph nodes from naïve $\mathrm{T}$ 
cells (79). Based on this premise, we found that the proportion of Helios $^{-}$iTreg cells was significantly higher in the decidua compared to the peripheral blood (38). Interestingly, our results also indicate that the previously described peripheral blood expansion of Treg cells associated with healthy pregnancy is accounted for by the expansion of iTreg cells, and not nTreg cells. This suggests that in healthy pregnancy, iTreg cells are induced locally in the decidua/draining lymph nodes most likely in response to fetal allo-antigens. This observation is consistent with the murine studies previously discussed $(72,73)$, as well as the fact that iTreg cells are thought to facilitate tolerance to foreign- (in this case fetal) and self-antigens, whereas nTreg cells are primarily involved in self-tolerance $(67,80,81)$.

Functionally, in vivo experiments in the murine model have shown that Treg cells are important for fetal-maternal immune tolerance. Aluvihare et al. showed that adoptive transfer of whole $\mathrm{T}$ cell populations to $\mathrm{T}$ cell-deficient pregnant mice did not result in fetal rejection, whereas transfer of T cells depleted of CD25 ${ }^{+}$ Treg cells led to fetal demise, especially in allogeneic pregnancies (70). This was confirmed by another method, where PC61 monoclonal antibody against CD25 was used to deplete Tregs in murine syngeneic and allogeneic pregnancy. The authors found that fewer fetuses in allogeneic pregnancies survived to term whereas syngeneic pregnancies were not affected by Treg cell depletion (82). This indicates that Treg cells are critically required for allogeneic but not syngeneic pregnancy.

Whereas total Treg cell depletion leads to almost complete fetal rejection $(70,82)$, depletion of the iTreg, but not nTreg, compartment in CNS1 (conserved non-coding sequence 1) deficient mice (CNS1 being critical for iTreg development) leads to partial fetal resorption $(\sim 10 \%)$ and abnormal spiral artery formation in allogeneic murine pregnancies (83). This phenotype is reminiscent of the human disease - pre-eclampsia, where IUGR (intrauterine growth retardation) and abnormal spiral artery remodeling with shallow placentation is a key pathological feature (84), being mindful of the caveat that there are significant differences between human and murine pregnancies (85).

Nevertheless, our investigations did show that the blunted peripheral blood Treg cell expansion in pre-eclampsia $(69,86,87)$ is primarily due to the failure of iTreg cell expansion, whereas nTreg cells are not affected. Interestingly in the pre-eclamptic decidua, whilst we did not find a reduction in total Treg cell percentage, there was a significant reduction in the percentage of Helios ${ }^{-}$ iTreg cells compared to healthy pregnancy (38). These observations suggest that in pre-eclampsia, there is impaired expansion of iTreg cells in the decidua, with compensatory nTreg cell recruitment to avert fetal rejection. Collectively, these data from murine and human studies suggest that iTreg and nTreg cells collaborate to maintain fetal-maternal immune tolerance, such that complete lack of Treg cells leads to fetal rejection, whereas specific iTreg cell deficiency results in poor placentation and fetal growth restriction.

\section{Th17 CELLS IN HEALTHY PREGNANCY AND PRE-ECLAMPSIA}

Th17 cells are a subset of CD4 ${ }^{+}$T helper cells, which secrete the pro-inflammatory cytokines IL-17, IL-22, regulated by the transcription factor ROR $\gamma \mathrm{t}$ (88). Importantly, both iTreg and Th17 cells are derived from naïve $\mathrm{CD} 4^{+} \mathrm{T}$ cells under the influence of
TGF $\beta$ (89) in a concentration-dependent manner, with high levels of TGF $\beta$ favoring iTreg cell induction and low concentrations favoring development of Th17 cells $(88,90)$. Additionally, the presence of the pro-inflammatory cytokine, IL-6 is crucial for skewing T cell differentiation toward Th17 phenotype (91).

We have previously shown that the percentage of peripheral blood Th17 cells decreases in healthy pregnancy, in stark contrast to the expanding iTreg cell population. Whereas in pre-eclampsia, the percentages of peripheral blood Th17 and iTreg cell subsets remain comparable to the non-pregnant state. This leads to an increased Treg: Th17 ratio in healthy pregnancy, which is blunted in pre-eclampsia (69). These results were later replicated in other studies $(92,93)$. Collectively, these observations are congruous with the raised serum IL-6 level in pre-eclampsia compared to healthy pregnancy (94), which may contribute to the increased Th17 cells compared to normal pregnancy. Additionally soluble endoglin, a circulating TGF $\beta$ glycoprotein receptor capable of inhibiting TGF $\beta$ signaling, is elevated in pre-eclampsia (95). This would likely reduce the degree of TGF $\beta$ signaling, hence favoring Th17 cell differentiation. Therefore, current evidence indicates that in healthy pregnancy, there is a preferential differentiation of iTreg cell over Th17 cells, which is deranged in pre-eclampsia, possibly related to altered systemic levels of various factors such as IL-6 and soluble endoglin (Figure 2).

Currently, few studies have examined Th17 cells in the human decidua. A study by Mjosberg et al. attempted to examine the proportions of Th1, Th2, Treg, and Th17 cells in early pregnancy decidua, however, in this study, the authors used chemokine receptors as surrogate markers for Th1, 2, and 17 cells, which is less than ideal, they concluded that there is near absence of Th17 cells in early healthy pregnancy decidua (96). Wang et al. found increased peripheral blood and decidual Th17 cell percentage in women with unexplained recurrent miscarriages compared to healthy pregnancy. In their samples, the percentage of Th17 cells in the decidua appears to be comparable or even slightly lower than in

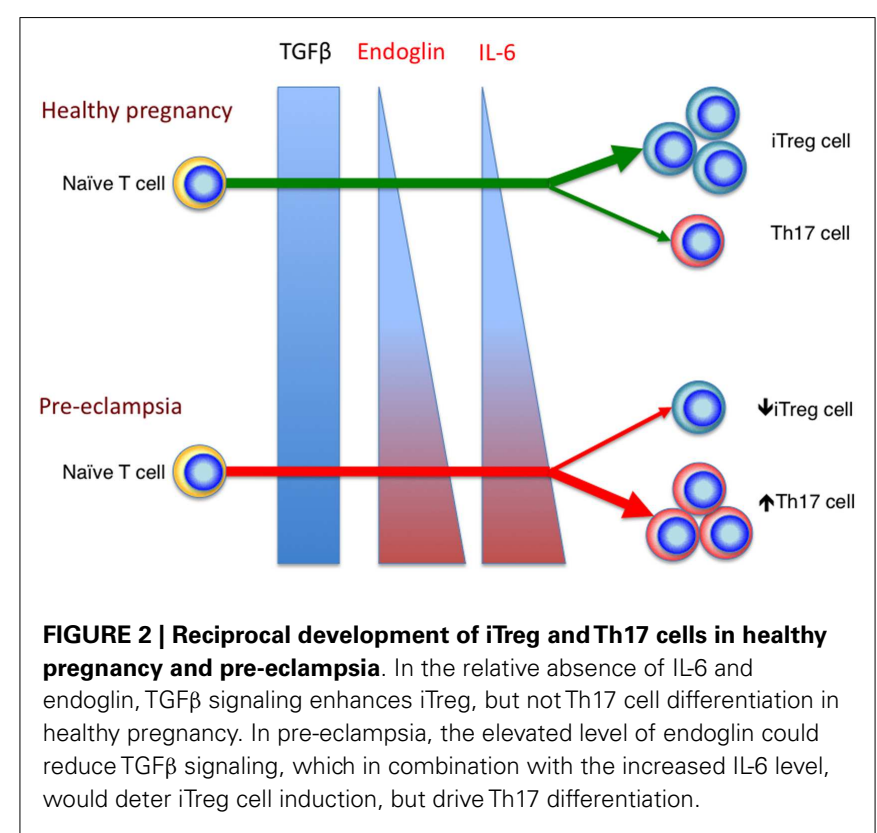


peripheral blood in both study groups (97). This is in contrast to another study, which showed higher percentages of Th17 cells in the decidua in healthy pregnancy (98). Therefore, current evidence demonstrates that Th17 cells are present in the decidua, although their prevalence is controversial. Furthermore, no study to date has examined the presence and prevalence of decidual Th17 cells in pre-eclampsia. It would be interesting to see whether there is an increase in decidual Th17 cells in pre-eclampsia, which would add to the body of evidence implicating local immune dysregulation in this disease.

\section{CD4 $^{+}$HLA-G $^{+}$T CELLS IN HEALTHY PREGNANCY AND PRE-ECLAMPSIA}

HLA-G is an atypical MHC class I molecule first discovered on human trophoblasts $(99,100)$. It exerts immunosuppressive effects on various immune cells, including APCs, NK cells, and T cells (101-103). Therefore, it is not surprising that it is expressed at immune privileged sites such as the decidua (99), the cornea (104), and thymic medulla (105). Interestingly, distinct subsets of $\mathrm{HLA}_{-} \mathrm{G}^{+} \mathrm{T}$ cells (both $\mathrm{CD}^{+}$and $\mathrm{CD}^{+}$) are present at low levels in the peripheral blood of healthy donors (106). These cells are immunosuppressive but do not express Foxp3. They mediate suppression in a HLA-G and IL-10-dependent manner (107). Some evidence suggests that these cells originate from the thymus (106), however others have also shown that activated T cells can also "acquire" HLA-G from HLA-G expressing APCs, through the process of trogocytosis (108). Trogocytosis is a process by which membrane fragments including surface molecules are transferred from one cell to another in a contact-dependent manner (109). These HLA-G expressing T cells are similarly immunosuppressive $(108,110)$.

We and others have shown that the percentage of peripheral blood $\mathrm{CD}^{+}{ }^{+} \mathrm{HLA}_{-\mathrm{G}}{ }^{+} \mathrm{T}$ cells is significantly increased in healthy pregnancy, which is even more pronounced within the decidua, where up to $20 \%$ of the $\mathrm{CD}^{+}{ }^{+}$T cells are $\mathrm{HLA}_{-\mathrm{G}^{+}}(46$, 111). These $\mathrm{CD}^{+}{ }^{+} \mathrm{HLA}-\mathrm{G}^{+} \mathrm{T}$ cells are more mature and activated than their HLA-G ${ }^{-}$counterparts, they are Foxp $3^{-}$but are immunosuppressive (46). Importantly, in pre-eclampsia there is impaired expansion of these $\mathrm{CD}^{+}{ }^{+} \mathrm{HLA}-\mathrm{G}^{+} \mathrm{T}$ cells in both the peripheral blood and the decidua. This is in keeping with the reduced serum HLA-G and placental HLA-G level in this disease, and reinforces the dysregulated adaptive immune responses in pre-eclampsia.

\section{INNATE AND ADAPTIVE INTERACTION AT THE FETAL-MATERNAL INTERFACE}

The evidence and discussions presented so far have focused on individual cell populations and their role in fetal-maternal immune tolerance, however, the immune system clearly does not work in isolation, but rather like an intricate, changing network. It is therefore important to investigate the interactions between the various immune cells, whether innate or adaptive at the fetalmaternal interface. In the following sections of this review, we will focus on the current available evidence in this regard and attempt to present a unifying concept, as well as future research directions for innate and adaptive immune interactions within the decidua.

\section{DECIDUAL NK CELL CROSSTALK WITH INNATE AND ADAPTIVE IMMUNE CELLS}

As discussed previously, dNK cells are important for modulating fetal trophoblast invasion and vascular remodeling. However, emerging evidence also suggests that dNK cells interact and modulate other maternal immune cells. Kammerer et al. first noted that $\mathrm{dNK}$ cells are closely associated with decidual DC-SIGN $^{+}$APCs. They further demonstrated that this interaction occurs through ICAM3 (expressed on NK cells) and DCSIGN interaction, although it was unclear what this interaction involves (41).

A later study demonstrated that $\mathrm{dNK}$ cells modulate decidual $\mathrm{CD}^{+}{ }^{+}$macrophages (dMac) to expand Treg cells in vitro (112). In this study, Vacca et al. demonstrated that interaction between $\mathrm{dMac}$ and $\mathrm{dNK}$ cells led to release of IFN $\gamma$ by dNK cells, the IFN $\gamma$ in turn induces upregulation of IDO in dMac. Importantly, IDO is known to contribute to immune suppression at the fetal-maternal interface $(113,114)$. It works by catabolizing tryptophan into Lkynurenine, which results in impaired $\mathrm{T}$ cell activation and favors Treg cell induction (115). Indeed, Vacca et al. showed that the IDO induction was important for subsequent Treg cell expansion by dMacs cultured with $\mathrm{dNK}$, along with other factors such as TGF $\beta$ and CTLA-4 engagement. Notably, CTLA-4 engagement of APC co-stimulatory B7 molecules has also been shown to upregulate IDO expression in APCs (116). This could provide a continuous positive reinforcement loop, where the expanded CTLA-4 expressing Treg cells further enhance APC IDO expression. Interestingly, L-kynurenine inhibited the ability of peripheral blood NK cells, but not dNK cells to secrete IFN $\gamma$, which may explain how this negative feedback prevents peripheral blood NK cells from modulating dMacs in the same way. Although the authors did not clarify, these "dMacs" are probably decidual DC-SIGN ${ }^{+}$APCs, which interact with ICAM3 $^{+} \mathrm{dNK}$ cells via DC-SIGN. It is also important to note that the authors did not clearly demonstrate de novo Treg cell induction under these conditions, since the starting peripheral blood $\mathrm{CD}^{+}$population would contain nTreg cell population. Nevertheless, the interaction between $\mathrm{dNK}$ and dMac appears to favor Treg cell proliferation and expansion through IFN $\gamma$-induced upregulation of IDO.

Interestingly, a more recent study showed that $\mathrm{dNK}$ production of IFN $\gamma$ may be important for averting Th17 differentiation at the fetal-maternal interface (55). Here, the authors found that $\mathrm{CD} 56^{\mathrm{hi}} \mathrm{CD} 27^{+} \mathrm{dNK}$ cells are particularly primed to secrete IFN $\gamma$, which has been shown to inhibit Th17 differentiation via STAT1 activation (117). They went on to show that in the murine model, deletion of NK cells led to increased Th17 cell accumulation in the decidua and increased fetal loss. In vitro, dNK cell-derived IFN $\gamma$ significantly inhibited Th17 cell differentiation, an effect that was reversed by IFN $\gamma$ neutralizing antibodies. Finally they showed that there is reduced $\mathrm{CD} 56{ }^{\mathrm{hi}} \mathrm{CD} 27^{+} \mathrm{dNK}$ cell:Th17 cell ratio in the decidua of women with recurrent miscarriages, accompanied by reduced IFN $\gamma$ secretion by dNK cells in these women. These results suggest that a special subset of $\mathrm{CD} 56^{\mathrm{hi}} \mathrm{CD} 27^{+} \mathrm{dNK}$ cells may be important for limiting Th17 cell differentiation and inflammation in normal pregnancy via IFN $\gamma$. It is intriguing to contemplate whether this inhibition of Th17 cell differentiation may 
paradoxically promote iTreg cell development, since both develop along the same pathway and reciprocally inhibit one another (84, 118). Furthermore, whether similar, but perhaps milder, pathophysiology may be found in pre-eclampsia is also of interest and requires further investigations.

Thus, these recent results highlight that NK cells are able to influence both decidual APCs and T cells through their secretion of IFN $\gamma$ to promote immune tolerance.

\section{APC AND T CELL INTERACTION AT THE FETAL-MATERNAL INTERFACE}

Antigen presenting cells play important roles in shaping $\mathrm{T}$ cell responses and differentiation; T cells in turn also modulate APC function. In our recent study, we showed by immunohistochemistry that decidual $\mathrm{DC}^{-\mathrm{SIGN}^{+}} \mathrm{APCs}$ are closely associated with Foxp $3^{+}$Treg cells (38). In fact the number of DC-SIGN ${ }^{+}$APCs correlated significantly with Foxp $3^{+}$Treg cells in healthy pregnancy, but interestingly not in pre-eclampsia, suggesting a dysregulated relationship between these cells in this disease. We went on to show that decidual $\mathrm{CD} 14^{+} \mathrm{DC}-\mathrm{SIGN}{ }^{+}$APCs from healthy pregnant, but not pre-eclamptic women induced iTreg cells significantly more efficiently than $\mathrm{CD}_{1}{ }^{+}$DC-SIGN ${ }^{-}$APCs. This suggests that there is an intrinsic defect in decidual CD $14^{+} \mathrm{DC}$ $\mathrm{SIGN}^{+}$APCs in pre-eclampsia. This is consistent with the reduced expression of the tolerogenic molecules HLA-G and ILT4 in this cell subset in pre-eclampsia. These results are also consistent with Vacca et al.'s study described in the previous section (112), and reinforce that decidual DC-SIGN ${ }^{+}$APCs are an important population of cells in human pregnancy, which likely present fetal allo-antigens and induce local iTreg cells. Importantly, in contrast to $\mathrm{CD}_{14}{ }^{+} \mathrm{DC}-\mathrm{SIGN}^{-}$APCs, decidual CD14 ${ }^{+} \mathrm{DC}^{-S I G N}{ }^{+}$APCs express CCR7 (38), which suggests that they may also migrate to uterine draining lymph nodes and induce iTreg cells there.

The unresolved question is how these $\mathrm{CD} 14^{+} \mathrm{DC}^{-\mathrm{SIGN}^{+}} \mathrm{APCs}$ induce iTreg cells. Vacca et al.'s study suggests that TGF $\beta$ and IDO may be required for this process (112). This raises another intriguing question, as to whether the elevated endoglin levels in pre-eclampsia may impair TGF $\beta$ signaling and impede iTreg cell induction whilst promoting Th17 differentiation. It is important to note however, that our experiments were done in vitro, removed from the in vivo environment where endoglin may play a role. Therefore, our data indicates that there may be an intrinsic defect in $\mathrm{CD}_{14}{ }^{+}$DC-SIGN ${ }^{+}$APCs in pre-eclampsia. Perhaps in pre-eclampsia, decidual $\mathrm{CD}_{14}{ }^{+} \mathrm{DC}-\mathrm{SIGN}^{+}$APCs secrete less TGF $\beta$, or have reduced IDO expression?

The abundance of immunosuppressive $\mathrm{CD} 4^{+} \mathrm{HLA}-\mathrm{G}^{+} \mathrm{T}$ cells in the decidua raises the question regarding how these cells have developed. Since HLA-G could be transferred from cell to cell via trogocytosis $(108,110,119)$, we reasoned that these CD4 ${ }^{+} \mathrm{T}$ cells could have acquired HLA-G from any of the HLA-G expressing cells in the decidua, including fetal EVT and maternal CD $14^{+} \mathrm{DC}-$ $\mathrm{SIGN}^{+}$APCs. To this end, we showed that in vitro, decidual $\mathrm{CD}_{14}{ }^{+}$DC-SIGN ${ }^{+}$APCs, but not JEG3 cells (an EVT-like cell line), were able to induce $\mathrm{CD} 4^{+} \mathrm{HLA}_{-}{ }^{+} \mathrm{T}$ cells from naïve $\mathrm{T}$ cells (46). This is consistent with the fact that $\mathrm{T}$ cell trogocytosis is facilitated by the formation of immunological synapse with TCR-MHC engagement (120-122), since EVTs and JEG3 cells do not express MHC II. We further showed that the acquisition of HLA-G from T cells occurred via trogocytosis, since PE labeled HLA-G was passed from the APC to responding T cells. Therefore, we suggest that in the human decidua, $\mathrm{T}$ cells activated by fetal allo-antigens may be "silenced" by their acquisition of HLA-G, indeed the HLA-G expressing $\mathrm{T}$ cells in the decidua exhibit an activated phenotype (46). Importantly in pre-eclampsia, there is significant reduction of $\mathrm{CD} 4{ }^{+} \mathrm{HLA}_{-} \mathrm{G}^{+} \mathrm{T}$ cells, which may be secondary to the reduced HLA-G expression by decidual $\mathrm{CD}_{14}{ }^{+} \mathrm{DC}-\mathrm{SIGN}{ }^{+}$APCs in this disease.

Based on these recent data, it appears that decidual CD14 ${ }^{+} \mathrm{DC}-$ $\mathrm{SIGN}^{+}$APCs are a unique and important population of cells, which play central roles in regulating local immune responses by their interactions with $\mathrm{dNK}$ cells and resident $\mathrm{CD} 4^{+} \mathrm{T}$ cells. As described previously, decidual CD $14^{+}{ }^{D C}-S_{G N}{ }^{+}$APCs may have developed under the influence of local IL-10 $(42,46)$, which is probably derived from $\mathrm{dNK}$ and $\mathrm{CD} 14^{+} \mathrm{DC}-\mathrm{SIGN}^{-} \mathrm{dMac}(41)$.

Therefore, IL-10 may be a central cytokine driving the differentiation of decidual tolerogenic APCs and suppressor T cells. Interestingly, IL-10 is dispensable for murine pregnancy in the germ free environment, but crucial when LPS is present (57), suggesting that IL-10 is important for controlling inflammation at the fetalmaternal interface. This is not dissimilar to the gut where bacteria colonized, but not germ free mice, with IL-10 deficiency develop severe enterocolitis $(123,124)$, and humans with defects in IL-10 signaling pathway develop early onset inflammatory bowel disease $(125,126)$. In the gut, it has been shown that it is the pathogenic $\mathrm{T}$ cells that cause disease in the IL-10-deficient mice (81). Furthermore, recent evidence suggests that IL-10 may enhance Treg cell function and augment suppression of pathogenic Th17 cells (127, 128). It remains to be seen whether IL-10 plays similar roles in pregnancy. Nevertheless, it is clear that IL-10 is a crucial regulatory cytokine at mucosal surfaces in the presence of inflammation and foreign antigens. Indeed pre-eclampsia, rather than being an overt rejection of the fetus, is more like a pro-inflammatory state with flaws in the regulatory mechanisms, including reduced IL10 , altered decidual DC-SIGN ${ }^{+}$APCs, and impaired suppressor $\mathrm{T}$ cell (iTreg cells and CD4 ${ }^{+} \mathrm{HLA}_{-\mathrm{G}^{+}} \mathrm{T}$ cells) differentiation; further fueled by enhanced pro-inflammatory effectors such as raised IL-6 level and enhanced Th17 cell differentiation.

\section{CONCLUDING REMARKS}

The fetal-maternal interface is an important frontier for immunology, as it represents the junctional point between two immunologically distinct individuals. Within this mucosal surface, the various maternal innate and adaptive immune cells must work together to ensure tolerance toward invading fetal cells and foreign fetal antigens. Whilst several APCs are present in the decidua, CD14 ${ }^{+}$DC$\mathrm{SIGN}^{+}$APCs are unique at this interface and play central roles in regulating $\mathrm{T}$ cell responses, by inducing Foxp $3^{+}$iTreg cells and $\mathrm{CD}^{+}{ }^{+} \mathrm{HLA}_{-} \mathrm{G}^{+}$suppressor $\mathrm{T}$ cells. Some evidence suggests that IL-10 may be an important factor in these processes. Certainly in pre-eclampsia, where there is relative deficiency of IL-10, these tolerance mechanisms are impaired. Whether $\mathrm{CD} 14^{+} \mathrm{DC}^{\mathrm{SIGN}}{ }^{+}$ APCs also influence decidual Th17 cell differentiation remains unknown and requires further investigations.

On the other hand, decidual NK cells, on top of their role in modulating trophoblast invasion and vascular remodeling, are able 


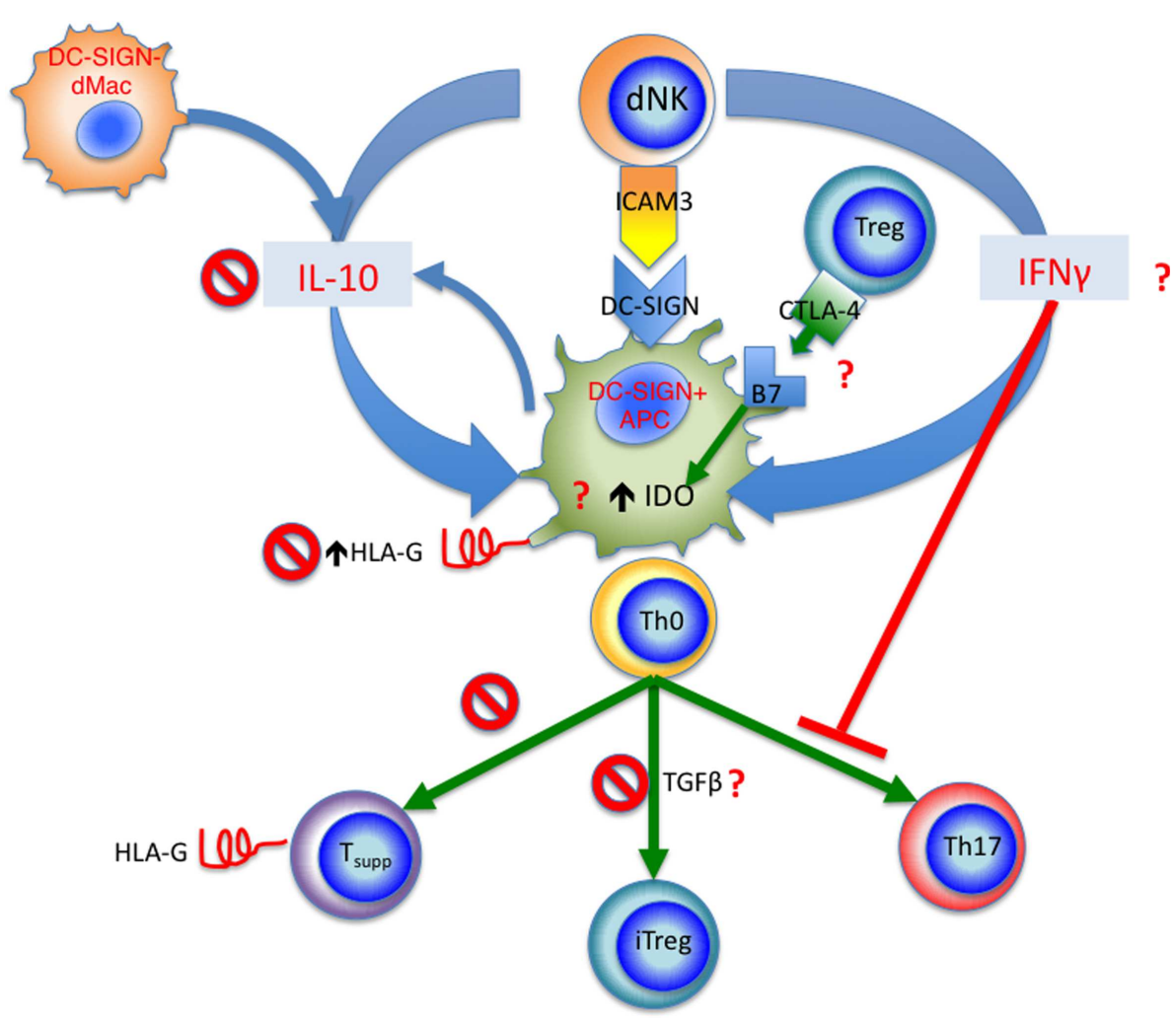

FIGURE 3 | Summary of proposed innate and adaptive interactions in human pregnancy. Decidual DC-SIGN ${ }^{+}$APCs appear to be a central player in these interactions. dNK cells interact with DC-SIGN ${ }^{+}$APCs via ICAM3, this leads to release of IFN $\gamma$, which in turn upregulates IDO in DC-SIGN+ APCs, as well as inhibiting Th17 cell differentiation. The tolerogenic DC-SIGN ${ }^{+}$APCs function to induce iTreg cells from naïve $\mathrm{CD} 4^{+} \mathrm{T}$ cells (Th0), Treg cells in turn regulated DC-SIGN+ APCs via CTLA-4 and B7 (CD80 and CD86) interaction, further increasing IDO expression. IL-10 from dNK cells and DC-SIGN ${ }^{-}$dMacs acts to upregulate HLA-G expression by DC-SIGN+ APCs; the HLA-G is then passed onto activated $T$ cells via trogocytosis, resulting in accumulation of $\mathrm{CD}^{+}{ }^{+} \mathrm{HLA}-\mathrm{G}^{+} \mathrm{T}$ suppressor cells. In pre-eclampsia, several check points are affected as marked by the "No symbol." These include reduced IL-10 level, reduced HLA-G expression by DC-SIGN+ APCs, reduced generation of $\mathrm{CD}^{+}{ }^{+} \mathrm{HLA}-\mathrm{G}^{+} \mathrm{T}$ suppressor cells, and reduced iTreg cell induction. Other yet unknown mechanisms may also be affected in pre-eclampsia marked by the red question mark, including IFN $\gamma$ production by dNKs, CTLA-4 expression by Treg cells and interaction with B7 molecules, as well as IDO expression and TGF $\beta$ production by DC-SIGN ${ }^{+}$APCs. to regulate decidual Th17 differentiation by their production of IFN $\gamma$. Interestingly, their production of IFN $\gamma$ also modulate decidual $\mathrm{CD}_{14}{ }^{+}$DC-SIGN ${ }^{+}$APCs by upregulating their IDO expression to enhance Treg cell expansion. Whether these processes are affected in pre-eclampsia remain to be seen. These interactions are summarized in Figure 3. Clearly, there are likely many other innate and adaptive interactions involving different cell types, which work to foster the delicate balance of immune tolerance at the fetalmaternal interface. Disturbance of the quality and quantity of these interactions likely contribute to the pathogenesis of preeclampsia, which like so many diseases of the modern era, is a disease of immune dysregulation.

\section{REFERENCES}

1. Medawar PB. Some immunological and endocrinological problems raised by evolution of viviparity in vertebrates. Symp Soc Exp Biol (1953) 7: 320-8.

2. Apps R, Murphy SP, Fernando R, Gardner L, Ahad T, Moffett A. Human leucocyte antigen (HLA) expression of primary trophoblast cells and placental cell lines, determined using single antigen beads to characterize allotype specificities of anti-HLA antibodies. Immunology (2009) 127(1):26-39. doi:10.1111/j.1365-2567.2008.03019.x
3. Nelson JL. Microchimerism: incidental byproduct of pregnancy or active participant in human health? Trends Mol Med (2002) 8(3):109-13. doi:10.1016/ S1471-4914(01)02269-9

4. Nelson JL. Microchimerism in human health and disease. Autoimmunity (2003) 36(1):5-9. doi:10.1080/0891693031000067304

5. Morin-Papunen L, Tiilikainen A, Hartikainen-Sorri AL. Maternal HLA immunization during pregnancy: presence of anti HLA antibodies in half of multigravidous women. Med Biol (1984) 62(6):323-5.

6. Lee J, Romero R, Xu Y, Miranda J, Yoo W, Chaemsaithong P, et al. Detection of anti-HLA antibodies in maternal blood in the second trimester to identify patients at risk of antibody-mediated maternal anti-fetal rejection and spontaneous preterm delivery. Am J Reprod Immunol (2013) 70(2):162-75. doi:10.1111/aji.12141

7. Erlebacher A, Vencato D, Price KA, Zhang D, Glimcher LH. Constraints in antigen presentation severely restrict $\mathrm{T}$ cell recognition of the allogeneic fetus. J Clin Invest (2007) 117(5):1399-411. doi:10.1172/JCI28214

8. Geiselhart A, Dietl J, Marzusch K, Ruck P, Ruck M, Horny HP, et al. Comparative analysis of the immunophenotypes of decidual and peripheral blood large granular lymphocytes and T cells during early human pregnancy. Am J Reprod Immunol (1995) 33(4):315-22. doi:10.1111/j.1600-0897.1995.tb00900.x

9. Redman CW, Sargent IL. Immunology of pre-eclampsia. Am J Reprod Immunol (2010) 63(6):534-43. doi:10.1111/j.1600-0897.2010.00831.x

10. Wilczynski JR. Immunological analogy between allograft rejection, recurrent abortion and pre-eclampsia - the same basic mechanism? Hum Immunol (2006) 67(7):492-511. doi:10.1016/j.humimm.2006.04.007 
11. Young BC, Levine RJ, Karumanchi SA. Pathogenesis of preeclampsia. Annu Rev Pathol (2010) 5:173-92. doi:10.1146/annurev-pathol-121808-102149

12. Roberts JM, Taylor RN, Goldfien A. Clinical and biochemical evidence of endothelial cell dysfunction in the pregnancy syndrome preeclampsia. Am J Hypertens (1991) 4(8):700-8.

13. Gardner L, Moffett A. Dendritic cells in the human decidua. Biol Reprod (2003) 69(4):1438-46. doi:10.1095/biolreprod.103.017574

14. Ban YL, Kong BH, Qu X, Yang QF, MaYY. BDCA-1+, BDCA-2+ and BDCA-3+ dendritic cells in early human pregnancy decidua. Clin Exp Immunol (2008) 151(3):399-406. doi:10.1111/j.1365-2249.2007.03576.x

15. Kammerer U, Schoppet M, McLellan AD, Kapp M, Huppertz HI, Kampgen E, et al. Human decidua contains potent immunostimulatory CD83(+) dendritic cells. Am J Pathol (2000) 157(1):159-69. doi:10.1016/S0002-9440(10) 64527-0

16. Laskarin G, Redzovic A, Rubesa Z, Mantovani A, Allavena P, Haller H, et al. Decidual natural killer cell tuning by autologous dendritic cells. Am J Reprod Immunol (2008) 59(5):433-45. doi:10.1111/j.1600-0897.2008.00599.x

17. Miyazaki S, Tsuda H, Sakai M, Hori S, Sasaki Y, Futatani T, et al. Predominance of Th2-promoting dendritic cells in early human pregnancy decidua. J Leukoc Biol (2003) 74(4):514-22. doi:10.1189/jlb.1102566

18. Plaks V, Birnberg T, Berkutzki T, Sela S, BenYashar A, Kalchenko V, et al. Uterine DCs are crucial for decidua formation during embryo implantation in mice. J Clin Invest (2008) 118(12):3954-65. doi:10.1172/JCI36682

19. Collins MK, Tay C-S, Erlebacher A. Dendritic cell entrapment within the pregnant uterus inhibits immune surveillance of the maternal/fetal interface in mice. J Clin Invest (2009) 119(7):2062-73. doi:10.1172/JCI38714

20. Red-Horse K, Drake PM, Fisher SJ. Human pregnancy: the role of chemokine networks at the fetal-maternal interface. Expert Rev Mol Med (2004) 6(11):1-14. doi:10.1017/S1462399404007720

21. Red-Horse K. Lymphatic vessel dynamics in the uterine wall. Placenta (2008) 29(Suppl A):S55-9. doi:10.1016/j.placenta.2007.11.011

22. Huang SJ, Chen CP, Schatz F, Rahman M, Abrahams VM, Lockwood CJ. Preeclampsia is associated with dendritic cell recruitment into the uterine decidua. J Pathol (2008) 214(3):328-36. doi:10.1002/path.2257

23. Scholz C, Toth B, Santoso L, Kuhn C, Franz M, Mayr D, et al. Distribution and maturity of dendritic cells in diseases of insufficient placentation. Am J Reprod Immunol (2008) 60(3):238-45. doi:10.1111/j.1600-0897.2008.00619.x

24. Hume DA. The mononuclear phagocyte system. Curr Opin Immunol (2006) 18(1):49-53. doi:10.1016/j.coi.2005.11.008

25. Hume DA. Macrophages as APC and the dendritic cell myth. J Immunol (2008) 181(9):5829-35.

26. Bulmer JN, Johnson PM. Macrophage populations in the human placenta and amniochorion. Clin Exp Immunol (1984) 57(2):393-403.

27. Heikkinen J, Mottonen M, Komi J, Alanen A, Lassila O. Phenotypic characterization of human decidual macrophages. Clin Exp Immunol (2003) 131(3):498-505. doi:10.1046/j.1365-2249.2003.02092.x

28. Repnik U, Tilburgs T, Roelen DL, van der Mast BJ, Kanhai HH, Scherjon $\mathrm{S}$, et al. Comparison of macrophage phenotype between decidua basalis and decidua parietalis by flow cytometry. Placenta (2008) 29(5):405-12. doi:10.1016/j.placenta.2008.02.004

29. Gustafsson C, Mjosberg J, Matussek A, Geffers R, Matthiesen L, Berg G, et al. Gene expression profiling of human decidual macrophages: evidence for immunosuppressive phenotype. PLoS One (2008) 3(4):e2078. doi:10.1371/ journal.pone.0002078

30. Mizuno M, Aoki K, Kimbara T. Functions of macrophages in human decidual tissue in early pregnancy. Am J Reprod Immunol (1994) 31(4):180-8. doi:10.1111/j.1600-0897.1994.tb00865.x

31. Parhar RS, Kennedy TG, Lala PK. Suppression of lymphocyte alloreactivity by early gestational human decidua. I. Characterization of suppressor cells and suppressor molecules. Cell Immunol (1988) 116(2):392-410. doi:10.1016/0008-8749(88)90240-7

32. Smith SD, Dunk CE, Aplin JD, Harris LK, Jones RL. Evidence for immune cell involvement in decidual spiral arteriole remodeling in early human pregnancy. Am J Pathol (2009) 174(5):1959-71. doi:10.2353/ajpath.2009.080995

33. Cheong C, Matos I, Choi J-H, Dandamudi DB, Shrestha E, Longhi MP, et al. Microbial stimulation fully differentiates monocytes to DC-SIGN/CD209(+) dendritic cells for immune T cell areas. Cell (2010) 143(3):416-29. doi:10.1016/ j.cell.2010.09.039
34. Nagamatsu T, Schust DJ. The immunomodulatory roles of macrophages at the maternal-fetal interface. Reprod Sci (2010) 17(3):209-18. doi:10.1177/ 1933719109349962

35. Rieger L, Segerer S, Bernar T, Kapp M, Majic M, Morr A-K, et al. Specific subsets of immune cells in human decidua differ between normal pregnancy and preeclampsia - a prospective observational study. Reprod Biol Endocrinol (2009) 7:132. doi:10.1186/1477-7827-7-132

36. Schonkeren D, van der Hoorn M-L, Khedoe P, Swings G, van Beelen E, Claas $\mathrm{F}$, et al. Differential distribution and phenotype of decidual macrophages in preeclamptic versus control pregnancies. Am J Pathol (2011) 178(2):709-17. doi:10.1016/j.ajpath.2010.10.011

37. Bockle BC, Solder E, Kind S, Romani N, Sepp NT. DC-sign+ CD163+ macrophages expressing hyaluronan receptor LYVE-1 are located within chorion villi of the placenta. Placenta (2008) 29(2):187-92. doi:10.1016/j. placenta.2007.11.003

38. Hsu P, Santner-Nanan B, Dahlstrom J, Fadia M, Chandra A, Peek M, et al. Altered decidual DC-SIGN+ antigen presenting cells and impaired regulatory T cell induction in preeclampsia. Am J Pathol (2012) 181(6):2149-60. doi:10.1016/j.ajpath.2012.08.032

39. Geijtenbeek TB, Torensma R, van Vliet SJ, van Duijnhoven GC, Adema GJ, van Kooyk Y, et al. Identification of DC-SIGN, a novel dendritic cell-specific ICAM-3 receptor that supports primary immune responses. Cell (2000) 100(5):575-85. doi:10.1016/S0092-8674(00)80693-5

40. Soilleux EJ, Morris LS, Leslie G, Chehimi J, Luo Q, Levroney E, et al. Constitutive and induced expression of DC-SIGN on dendritic cell and macrophage subpopulations in situ and in vitro. J Leukoc Biol (2002) 71(3): 445-57.

41. Kammerer U, Eggert AO, Kapp M, McLellan AD, Geijtenbeek TB, Dietl J, et al. Unique appearance of proliferating antigen-presenting cells expressing DCSIGN (CD209) in the decidua of early human pregnancy. Am J Pathol (2003) 162(3):887-96. doi:10.1016/S0002-9440(10)63884-9

42. Svensson J, Jenmalm MC, Matussek A, Geffers R, Berg G, Ernerudh J. Macrophages at the fetal-maternal interface express markers of alternative activation and are induced by M-CSF and IL-10. J Immunol (2011) 187(7):3671-82. doi:10.4049/jimmunol.1100130

43. Houser BL, Tilburgs T, Hill J, Nicotra ML, Strominger JL. Two unique human decidual macrophage populations. J Immunol (2011) 186(4):2633-42. doi:10.4049/jimmunol.1003153

44. Manavalan JS, Rossi PC, Vlad G, Piazza F, Yarilina A, Cortesini R, et al. High expression of ILT3 and ILT4 is a general feature of tolerogenic dendritic cells. Transpl Immunol (2003) 11(3-4):245-58. doi:10.1016/S0966-3274(03)000583

45. Moreau P, Adrian-Cabestre F, Menier C, Guiard V, Gourand L, Dausset J, et al. IL-10 selectively induces HLA-G expression in human trophoblasts and monocytes. Int Immunol (1999) 11(5):803-11. doi:10.1093/intimm/11.5.803

46. Hsu P, Santner-Nanan B, Joung S, Peek MJ, Nanan R. Expansion of CD4 HLA-G $\mathrm{T}$ cell in human pregnancy is impaired in pre-eclampsia. Am J Reprod Immunol (2014) 71(3):217-28. doi:10.1111/aji.12195

47. Hennessy A, Pilmore HL, Simmons LA, Painter DM. A deficiency of placental IL-10 in preeclampsia. J Immunol (1999) 163(6):3491-5.

48. King A. Uterine leukocytes and decidualization. Hum Reprod Update (2000) 6(1):28-36. doi:10.1093/humupd/6.1.28

49. Carlino C, Stabile H, Morrone S, Bulla R, Soriani A, Agostinis C, et al. Recruitment of circulating NK cells through decidual tissues: a possible mechanism controlling NK cell accumulation in the uterus during early pregnancy. Blood (2008) 111(6):3108-15. doi:10.1182/blood-2007-08-105965

50. Spornitz UM. The functional morphology of the human endometrium and decidua. Adv Anat Embryol Cell Biol (1992) 124:1-99. doi:10.1007/978-3-64258099-4_1

51. Boyington JC, Brooks AG, Sun PD. Structure of killer cell immunoglobulin-like receptors and their recognition of the class I MHC molecules. Immunol Rev (2001) 181:66-78. doi:10.1034/j.1600-065X.2001.1810105.x

52. King A, Allan DS, Bowen M, Powis SJ, Joseph S, Verma S, et al. HLA-E is expressed on trophoblast and interacts with CD94/NKG2 receptors on decidual NK cells. Eur J Immunol (2000) 30(6):1623-31. doi:10.1002/15214141(200006)30:6<1623::AID-IMMU1623>3.0.CO;2-M

53. Long EO, Barber DF, Burshtyn DN, Faure M, Peterson M, Rajagopalan S, et al. Inhibition of natural killer cell activation signals by killer cell 
immunoglobulin-like receptors (CD158). Immunol Rev (2001) 181:223-33. doi:10.1034/j.1600-065X.2001.1810119.x

54. Hiby SE, Apps R, Sharkey AM, Farrell LE, Gardner L, Mulder A, et al. Maternal activating KIRs protect against human reproductive failure mediated by fetal HLA-C2. J Clin Invest (2010) 120(11):4102-10. doi:10.1172/ JCI43998

55. Xiong S, Sharkey AM, Kennedy PR, Gardner L, Farrell LE, Chazara O, et al. Maternal uterine NK cell-activating receptor KIR2DS1 enhances placentation. J Clin Invest (2013) 123(10):4264-72. doi:10.1172/JCI68991

56. Rajagopalan S, Bryceson YT, Kuppusamy SP, Geraghty DE, van der Meer A, Joosten I, et al. Activation of NK cells by an endocytosed receptor for soluble HLA-G. PLoS Biol (2006) 4(1):e9. doi:10.1371/journal.pbio.0040009

57. Murphy SP, Fast LD, Hanna NN, Sharma S. Uterine NK cells mediate inflammation-induced fetal demise in IL-10-null mice. J Immunol (2005) 175(6):4084-90.

58. Duckitt K, Harrington D. Risk factors for pre-eclampsia at antenatal booking: systematic review of controlled studies. BMJ (2005) 330(7491):565. doi:10.1136/bmj.38380.674340.E0

59. Li DK, Wi S. Changing paternity and the risk of preeclampsia/eclampsia in the subsequent pregnancy. Am J Epidemiol (2000) 151(1):57-62. doi:10.1093/ oxfordjournals.aje.a010122

60. Fan D-X, Duan J, Li M-Q, Xu B, Li D-J, Jin L-P. The decidual gammadelta $\mathrm{T}$ cells up-regulate the biological functions of trophoblasts via IL-10 secretion in early human pregnancy. Clin Immunol (2011) 141(3):284-92. doi:10.1016/j.clim.2011.07.008

61. Tilburgs T, Schonkeren D, Eikmans M, Nagtzaam NM, Datema G, Swings GM, et al. Human decidual tissue contains differentiated CD8+ effectormemory T cells with unique properties. J Immunol (2010) 185(7):4470-7. doi:10.4049/jimmunol.0903597

62. Tilburgs T, Roelen DL, van der Mast BJ, van Schip JJ, Kleijburg C, de Groot-Swings GM, et al. Differential distribution of CD4(+)CD25(bright) and CD8(+)CD28(-) T-cells in decidua and maternal blood during human pregnancy. Placenta (2006) 27(Suppl A):S47-53. doi:10.1016/j.placenta.2005.11. 008

63. Saito S, Tsukaguchi N, Hasegawa T, Michimata T, Tsuda H, Narita N. Distribution of Th1, Th2, and Th0 and the Th1/Th2 cell ratios in human peripheral and endometrial T cells. Am J Reprod Immunol (1999) 42(4):240-5. doi:10.1111/j.1600-0897.1999.tb00097.x

64. Sakaguchi S, Yamaguchi T, Nomura T, Ono M. Regulatory T cells and immune tolerance. Cell (2008) 133(5):775-87. doi:10.1016/j.cell.2008.05.009

65 . Wing K, Sakaguchi S. Regulatory T cells exert checks and balances on self tolerance and autoimmunity. Nat Immunol (2010) 11(1):7-13. doi:10.1038/ni.1818

66. Wood KJ, Sakaguchi S. Regulatory T cells in transplantation tolerance. Nat Rev Immunol (2003) 3(3):199-210. doi:10.1038/nri1027

67. Bilate AM, Lafaille JJ. Induced $\mathrm{CD} 4(+) \operatorname{Foxp} 3(+)$ regulatory $\mathrm{T}$ Cells in immune tolerance. Annu Rev Immunol (2012) 30:733-58. doi:10.1146/ annurev-immunol-020711-075043

68. Somerset DA, Zheng Y, Kilby MD, Sansom DM, Drayson MT. Normal human pregnancy is associated with an elevation in the immune suppressive CD25+ CD4+ regulatory T-cell subset. Immunology (2004) 112(1):38-43. doi:10.1111/j.1365-2567.2004.01869.x

69. Santner-Nanan B, Peek MJ, Khanam R, Richarts L, Zhu E, Fazekas de St Groth B, et al. Systemic increase in the ratio between Foxp3+ and IL-17-producing $\mathrm{CD} 4+\mathrm{T}$ cells in healthy pregnancy but not in preeclampsia. J Immunol (2009) 183(11):7023-30. doi:10.4049/jimmunol.0901154

70. Aluvihare VR, Kallikourdis M, Betz AG. Regulatory T cells mediate maternal tolerance to the fetus. Nat Immunol (2004) 5(3):266-71. doi:10.1038/ni1037

71. Zhao J-X, Zeng Y-Y, Liu Y. Fetal alloantigen is responsible for the expansion of the $\mathrm{CD} 4(+) \mathrm{CD} 25(+)$ regulatory $\mathrm{T}$ cell pool during pregnancy. J Reprod Immunol (2007) 75(2):71-81. doi:10.1016/j.jri.2007.06.052

72. Kahn DA, Baltimore D. Pregnancy induces a fetal antigen-specific maternal $\mathrm{T}$ regulatory cell response that contributes to tolerance. Proc Natl Acad Sci U S A (2010) 107(20):9299-304. doi:10.1073/pnas.1003909107

73. Rowe JH, Ertelt JM, Xin L, Way SS. Pregnancy imprints regulatory memory that sustains anergy to fetal antigen. Nature (2012) 490(7418):102-6. doi:10.1038/nature11462

74. Polanczyk MJ, Carson BD, Subramanian S, Afentoulis M, Vandenbark AA, Ziegler SF, et al. Cutting edge: estrogen drives expansion of the CD4+CD25+ regulatory T cell compartment. J Immunol (2004) 173(4):2227-30.
75. Arruvito L, Sanz M, Banham AH, Fainboim L. Expansion of CD4+CD25+and FOXP3+ regulatory $\mathrm{T}$ cells during the follicular phase of the menstrual cycle: implications for human reproduction. J Immunol (2007) 178(4):2572-8.

76. Prieto GA, Rosenstein Y. Oestradiol potentiates the suppressive function of human $\mathrm{CD} 4 \mathrm{CD} 25$ regulatory $\mathrm{T}$ cells by promoting their proliferation. Immunology (2006) 118(1):58-65. doi:10.1111/j.1365-2567.2006.02339.x

77. Heikkinen J, Mottonen M, Alanen A, Lassila O. Phenotypic characterization of regulatory $\mathrm{T}$ cells in the human decidua. Clin Exp Immunol (2004) 136(2):373-8. doi:10.1111/j.1365-2249.2004.02441.x

78. Tilburgs T, Roelen DL, van der Mast BJ, de Groot-Swings GM, Kleijburg C, Scherion SA, et al. Evidence for a selective migration of fetus-specific $\mathrm{CD} 4+\mathrm{CD} 25$ bright regulatory $\mathrm{T}$ cells from the peripheral blood to the decidua in human pregnancy. J Immunol (2008) 180(8):5737-45.

79. Thornton AM, Korty PE, Tran DQ, Wohlfert EA, Murray PE, Belkaid Y, et al. Expression of Helios, an Ikaros transcription factor family member, differentiates thymic-derived from peripherally induced Foxp3+ $\mathrm{T}$ regulatory cells. J Immunol (2010) 184(7):3433-41. doi:10.4049/jimmunol.0904028

80. Curotto de Lafaille MA, Lafaille JJ. Natural and adaptive foxp3+ regulatory T cells: more of the same or a division of labor? Immunity (2009) 30(5):626-35. doi:10.1016/j.immuni.2009.05.002

81. Yadav M, Stephan S, Bluestone JA. Peripherally induced tregs - role in immune homeostasis and autoimmunity. Front Immunol (2013) 4:232. doi:10.3389/ fimmu.2013.00232

82. Darrasse-Jeze G, Klatzmann D, Charlotte F, Salomon BL, Cohen JL. $\mathrm{CD} 4+\mathrm{CD} 25+$ regulatory/suppressor $\mathrm{T}$ cells prevent allogeneic fetus rejection in mice. Immunol Lett (2006) 102(1):106-9. doi:10.1016/j.imlet.2005.12.001

83. Samstein R, Josefowicz S, Arvey A, Treuting P, Rudensky A. Extrathymic generation of regulatory $\mathrm{T}$ cells in placental mammals mitigates maternal-fetal conflict. Cell (2012) 150(1):29-38. doi:10.1016/j.cell.2012.05.031

84. Lyall F, Robson SC, Bulmer JN. Spiral artery remodeling and trophoblast invasion in preeclampsia and fetal growth restriction: relationship to clinical outcome. Hypertension (2013) 62(6):1046-54. doi:10.1161/ HYPERTENSIONAHA.113.01892

85. Malassine A, Frendo JL, Evain-Brion D. A comparison of placental development and endocrine functions between the human and mouse model. Hum Reprod Update (2003) 9(6):531-9. doi:10.1093/humupd/dmg043

86. Prins JR, Boelens HM, Heimweg J, van der Heide S, Dubois AE, van Oosterhout AJ, et al. Preeclampsia is associated with lower percentages of regulatory T cells in maternal blood. Hypertens (2009) 28(3):300-11. doi:10.1080/ 10641950802601237

87. Toldi G, Svec P, Vasarhelyi B, Meszaros G, Rigo J, Tulassay T, et al. Decreased number of FoxP3+ regulatory T cells in preeclampsia. Acta Obstet Gynecol Scand (2008) 87(11):1229-33. doi:10.1080/00016340802389470

88. Korn T, Bettelli E, Oukka M, Kuchroo VK. IL-17 and Th17 cells. Annu Rev Immunol (2009) 27:485-517. doi:10.1146/annurev.immunol.021908.132710

89. Weaver CT, Harrington LE, Mangan PR, Gavrieli M, Murphy KM. Th17: an effector CD4 T cell lineage with regulatory T cell ties. Immunity (2006) 24(6):677-88. doi:10.1016/j.immuni.2006.06.002

90. Hatton RD. TGF-beta in Th17 cell development: the truth is out there. Immunity (2011) 34(3):288-90. doi:10.1016/j.immuni.2011.03.009

91. Kimura A, Kishimoto T. IL-6: regulator of Treg/Th17 balance. Eur J Immunol (2010) 40(7):1830-5. doi:10.1002/eji.201040391

92. Toldi G, Rigo J Jr, Stenczer B, Vasarhelyi B, Molvarec A. Increased prevalence of IL-17-producing peripheral blood lymphocytes in pre-eclampsia. Am J Reprod Immunol (2011) 66(3):223-9. doi:10.1111/j.1600-0897.2011.00987.x

93. Darmochwal-Kolarz D, Kludka-Sternik M, Tabarkiewicz J, Kolarz B, Rolinski J, Leszczynska-Gorzelak B, et al. The predominance of Th17 lymphocytes and decreased number and function of Treg cells in preeclampsia. J Reprod Immunol (2012) 93(2):75-81. doi:10.1016/j.jri.2012.01.006

94. Sharma A, Satyam A, Sharma JB. Leptin, IL-10 and inflammatory markers (TNF-alpha, IL-6 and IL-8) in pre-eclamptic, normotensive pregnant and healthy non-pregnant women. Am J Reprod Immunol (2007) 58(1):21-30. doi:10.1111/j.1600-0897.2007.00486.x

95. Levine RJ, Lam C, Qian C, Yu KF, Maynard SE, Sachs BP, et al. Soluble endoglin and other circulating antiangiogenic factors in preeclampsia. $N$ Engl J Med (2006) 355(10):992-1005. doi:10.1056/NEJMoa055352

96. Mjosberg J, Berg G, Jenmalm MC, Ernerudh J. FOXP3+ regulatory T cells and $\mathrm{T}$ helper $1, \mathrm{~T}$ helper 2 , and $\mathrm{T}$ helper 17 cells in human early pregnancy decidua. Biol Reprod (2010) 82(4):698-705. doi:10.1095/biolreprod.109.081208 
97. Wang W-J, Hao C-F, Yi L, Yin G-J, Bao S-H, Qiu L-H, et al. Increased prevalence of T helper 17 (Th17) cells in peripheral blood and decidua in unexplained recurrent spontaneous abortion patients. J Reprod Immunol (2010) 84(2):164-70. doi:10.1016/j.jri.2009.12.003

98. Nakashima A, Ito M, Yoneda S, Shiozaki A, Hidaka T, Saito S. Circulating and decidual Th17 cell levels in healthy pregnancy. Am J Reprod Immunol (2010) 63(2):104-9. doi:10.1111/j.1600-0897.2009.00771.x

99. Kovats S, Main EK, Librach C, Stubblebine M, Fisher SJ, DeMars R. A class I antigen, HLA-G, expressed in human trophoblasts. Science (1990) 248(4952):220-3. doi:10.1126/science.2326636

100. Ellis SA, Palmer MS, McMichael AJ. Human trophoblast and the choriocarcinoma cell line BeWo express a truncated HLA class I molecule. J Immunol (1990) 144(2):731-5.

101. Carosella ED, Gregori S, LeMaoult J. The tolerogenic interplay(s) among HLA-G, myeloid APCs, and regulatory cells. Blood (2011) 118(25):6499-505. doi:10.1182/blood-2011-07-370742

102. Rouas-Freiss N, Naji A, Durrbach A, Carosella ED. Tolerogenic functions of human leukocyte antigen $\mathrm{G}$ : from pregnancy to organ and cell transplantation. Transplantation (2007) 84(1 Suppl):S21-5. doi:10.1097/01.tp.0000269117. 32179.1c

103. Favier B, LeMaoult J, Carosella ED. Functions of HLA-G in the immune system. Tissue Antigens (2007) 69(Suppl 1):150-2. doi:10.1111/j.1399-0039.2006. 763_6.x

104. Le Discorde M, Moreau P, Sabatier P, Legeais J-M, Carosella ED. Expression of HLA-G in human cornea, an immune-privileged tissue. Hum Immunol (2003) 64(11):1039-44. doi:10.1016/j.humimm.2003.08.346

105. Mallet V, Blaschitz A, Crisa L, Schmitt C, Fournel S, King A, et al. HLA-G in the human thymus: a subpopulation of medullary epithelial but not CD83(+) dendritic cells expresses HLA-G as a membrane-bound and soluble protein. Int Immunol (1999) 11(6):889-98. doi:10.1093/intimm/11.6.889

106. Feger U, Tolosa E, Huang Y-H, Waschbisch A, Biedermann T, Melms A, et al. HLA-G expression defines a novel regulatory T-cell subset present in human peripheral blood and sites of inflammation. Blood (2007) 110(2):568-77. doi:10.1182/blood-2006-11-057125

107. Huang Y-H, Zozulya AL, Weidenfeller C, Schwab N, Wiendl H. T cell suppression by naturally occurring HLA-G-expressing regulatory CD4+ T cells is IL-10-dependent and reversible. J Leukoc Biol (2009) 86(2):273-81. doi:10.1189/jlb.1008649

108. LeMaoult J, Caumartin J, Daouya M, Favier B, Le Rond S, Gonzalez A, et al. Immune regulation by pretenders: cell-to-cell transfers of HLA-G make effector T cells act as regulatory cells. Blood (2007) 109(5):2040-8. doi:10.1182/ blood-2006-05-024547

109. Davis DM. Intercellular transfer of cell-surface proteins is common and can affect many stages of an immune response. Nat Rev Immunol (2007) 7(3):238-43. doi: 10.1038/nri2020

110. Brown R, Kabani K, Favaloro J, Yang S, Ho PJ, Gibson J, et al. CD86+ or HLA-G+ can be transferred via trogocytosis from myeloma cells to T cells and are associated with poor prognosis. Blood (2012) 120(10):2055-63. doi:10.1182/blood-2012-03-416792

111. Amodio G, Mugione A, Sanchez A, Vigano P, Candiani M, Somigliana E, et al. HLA-G expressing DC-10 and CD4(+) T cells accumulate in human decidua during pregnancy. Hum Immunol. (2013) 74(4):406-11. doi:10.1016/ j.humimm.2012.11.031

112. Vacca P, Cantoni C, Vitale M, Prato C, Canegallo F, Fenoglio D, et al. Crosstalk between decidual NK and CD14+ myelomonocytic cells results in induction of Tregs and immunosuppression. Proc Natl Acad Sci U S A (2010) 107(26):11918-23. doi:10.1073/pnas.1001749107

113. Miwa N, Hayakawa S, Miyazaki S, Myojo S, Sasaki Y, Sakai M, et al. IDO expression on decidual and peripheral blood dendritic cells and monocytes/macrophages after treatment with CTLA-4 or interferon-gamma increase in normal pregnancy but decrease in spontaneous abortion. Mol Hum Reprod (2005) 11(12):865-70. doi:10.1093/molehr/gah246

114. Mellor AL, Munn DH. Tryptophan catabolism prevents maternal T cells from activating lethal anti-fetal immune responses. J Reprod Immunol (2001) 52(1-2):5-13. doi:10.1016/S0165-0378(01)00118-8
115. Chen W, Liang X, Peterson AJ, Munn DH, Blazar BR. The indoleamine 2,3-dioxygenase pathway is essential for human plasmacytoid dendritic cell-induced adaptive $\mathrm{T}$ regulatory cell generation. J Immunol (2008) 181(8):5396-404

116. Puccetti P, Grohmann U. IDO and regulatory T cells: a role for reverse signalling and non-canonical NF-kappaB activation. Nat Rev Immunol (2007) 7(10):817-23. doi:10.1038/nri2163

117. Kim CJ, McKinnon LR, Kovacs C, Kandel G, Huibner S, Chege D, et al. Mucosal Th17 cell function is altered during HIV infection and is an independent predictor of systemic immune activation. J Immunol (2013) 191(5):2164-73. doi:10.4049/jimmunol.1300829

118. Ziegler SF, Buckner JH. FOXP3 and the regulation of Treg/Th17 differentiation. Microbes Infect (2009) 11(5):594-8. doi:10.1016/j.micinf.2009.04.002

119. Caumartin J, Favier B, Daouya M, Guillard C, Moreau P, Carosella ED, et al. Trogocytosis-based generation of suppressive NK cells. EMBO J (2007) 26(5):1423-33. doi:10.1038/sj.emboj.7601570

120. Huang JF, Yang Y, Sepulveda H, Shi W, Hwang I, Peterson PA, et al. TCRmediated internalization of peptide-MHC complexes acquired by T cells. Science (1999) 286(5441):952-4. doi:10.1126/science.286.5441.952

121. Stinchcombe JC, Bossi G, Booth S, Griffiths GM. The immunological synapse of CTL contains a secretory domain and membrane bridges. Immunity (2001) 15(5):751-61. doi:10.1016/S1074-7613(01)00234-5

122. Hudrisier D, Riond J, Mazarguil H, Gairin JE, Joly E. Cutting edge: CTLs rapidly capture membrane fragments from target cells in a TCR signaling-dependent manner. J Immunol (2001) 166(6):3645-9.

123. Kuhn R, Lohler J, Rennick D, Rajewsky K, Muller W. Interleukin-10-deficient mice develop chronic enterocolitis. Cell (1993) 75(2):263-74. doi:10.1016/ 0092-8674(93)80068-P

124. Sellon RK, Tonkonogy S, Schultz M, Dieleman LA, Grenther W, Balish E, et al. Resident enteric bacteria are necessary for development of spontaneous colitis and immune system activation in interleukin-10-deficient mice. Infect Immun (1998) 66(11):5224-31.

125. Glocker E-O, Kotlarz D, Boztug K, Gertz EM, Schaffer AA, Noyan F, et al. Inflammatory bowel disease and mutations affecting the interleukin-10 receptor. N Engl J Med (2009) 361(21):2033-45. doi:10.1056/NEJMoa0907206

126. Kotlarz D, Beier R, Murugan D, Diestelhorst J, Jensen O, Boztug K, et al. Loss of interleukin-10 signaling and infantile inflammatory bowel disease: implications for diagnosis and therapy. Gastroenterology (2012) 143(2):347-55. doi:10.1053/j.gastro.2012.04.045

127. Chaudhry A, Samstein RM, Treuting P, Liang Y, Pils MC, Heinrich J-M, et al. Interleukin-10 signaling in regulatory $\mathrm{T}$ cells is required for suppression of Th17 cell-mediated inflammation. Immunity (2011) 34(4):566-78. doi:10.1016/j.immuni.2011.03.018

128. Murai M, Turovskaya O, Kim G, Madan R, Karp CL, Cheroutre H, et al. Interleukin 10 acts on regulatory $\mathrm{T}$ cells to maintain expression of the transcription factor Foxp 3 and suppressive function in mice with colitis. Nat Immunol (2009) 10(11):1178-84. doi:10.1038/ni.1791

Conflict of Interest Statement: The authors declare that the research was conducted in the absence of any commercial or financial relationships that could be construed as a potential conflict of interest.

Received: 07 February 2014; paper pending published: 04 March 2014; accepted: 11 March 2014; published online: 28 March 2014.

Citation: Hsu P and Nanan RKH (2014) Innate and adaptive immune interactions at the fetal-maternal interface in healthy human pregnancy and pre-eclampsia. Front. Immunol. 5:125. doi: 10.3389/fimmu.2014.00125

This article was submitted to Inflammation, a section of the journal Frontiers in Immunology.

Copyright (C) 2014 Hsu and Nanan. This is an open-access article distributed under the terms of the Creative Commons Attribution License (CC BY). The use, distribution or reproduction in other forums is permitted, provided the original author(s) or licensor are credited and that the original publication in this journal is cited, in accordance with accepted academic practice. No use, distribution or reproduction is permitted which does not comply with these terms. 